\title{
GOTHIC/GIALLO/GENRE: HYBRID IMAGES IN ITALIAN HORROR CINEMA, 1956-82
}

Keith H. Brown

The University of Edinburgh

\begin{abstract}
Italian horror cinema is commonly divided into two periods and genres. An initial classical Gothic period spanned the years from 1956 to 1966 and was followed by a modern giallo (thriller) period from 1970 to 1982. Whilst accepting this broad distinction, this paper seeks to add nuance by considering the hybrid elements of three key films by three of the most important directors working in the giallo and horror area, namely Riccardo Freda with I Vampiri (1956), Mario Bava with The Girl Who Knew too Much (1963) and Dario Argento with Deep Red (1975). Drawing in particular upon Nöel Carroll's idea of "fearing fictions", I contend that Freda's film, the first Italian horror movie since the silent era, is notable for being a distinctively modern vampire film; that Bava's film, a foundational giallo, may be seen as having a palimpsest in Jane Austen's Gothic parody Northanger Abbey; and that Argento's film, while often taken as the paradigmatic giallo, has supernatural horror elements that push it in the direction of the Gothic.
\end{abstract}

Keywords: Giallo, Gothic, Italian Horror.

\begin{tabular}{|l|l|l|l|l|}
\hline Ilha do Desterro & Florianópolis & n 62 & p. 173- 194 & jan/jun 2012 \\
\hline
\end{tabular}




\section{Introduction/Overview}

In this essay I wish to explore some issues in relation to Italian horror cinema and the Gothic. This cinema has often been described as falling into two distinct temporal and sub-generic groupings (Günsberg 2005). 1956-66 is characterised as the Gothic period, 1970 onwards as the giallo period. As the reader is likely unfamiliar with this second term, a brief explanation is necessary. Giallo is Italian for yellow, and comes from the distinctive coloured covers in which translations of English-language mystery, thriller, and detective fiction were published by Mondadori, beginning in 1929. Giallo occupies a position comparable to the better known French noir, though the bodies of work encompassed by Serie noir and I libri gialli literature and by film noir and the giallo are somewhat different. ${ }^{1}$ Various points of distinction can also be made between the horror sub-genres. Italian Gothic films tended to be set in the past and in non-Italian locales, Gialli were generally set in the present and often in Italy. Gothic films tended to focus upon monsters, often vampires, whereas gialli foregrounded human murderers. Gothic films usually emphasised the supernatural, gialli a rational-scientific approach. Gothic films saw the cast and crew hide their Italian identities behind English sounding pseudonyms, whereas gialli were clearly of Italian origin. There were more gialli made, and these enjoyed greater commercial success overall.

Whilst not denying the general Gothic/giallo division, I intend to complicate it somewhat. I will do so through an examination of three exemplary films by major figures in Italian horror cinema. These are $I$ Vampiri/The Vampires (1956) by Riccardo Freda, The Girl Who Knew Too Much (1963) by Mario Bava, and Deep Red (1975) by Dario Argento. My contention is that regardless of whether these films are classified as Gothic or Giallo horrors they share an underlying 
point of origin and dynamics, as identified by Noël Carroll in The Philosophy of Horror (1990), yet cannot definitively be positioned as either Gothic or giallo horror on account of their hybrid elements

\section{Gothic/Horror}

As Fred Botting (109) notes in his historical overview of the Gothic the terms "Gothic" and "horror" are not synonymous. Some classics of Gothic literature cannot be considered works of horror, including Jane Austen's Northanger Abbey (1803/1817) and Charlotte Brontës Jane Eyre (1847). Some influential works of modern horror, such as Michael Reeves' film Matthew Hopkins: Witchfinder General (1968) and George A. Romero's Dawn of the Dead (1978), have few if any Gothic elements. This said, there is considerable overlap between the two forms, as demonstrated by the composite term "Gothic horror".

Botting also reminds us that through most of the twentiethcentury $^{2}$ cinema was the main vehicle through which people encountered the Gothic. This can be seen from a consideration of two of the most famous works of nineteenth-century Gothic literature, Mary Shelley's Frankenstein (1819) and Bram Stoker's Dracula (1897). Our dominant images of these texts come from films like James Whale's Frankenstein (1931) and Terence Fisher's Dracula (1958). We think of Christopher Lee wearing an opera cloak or Boris Karloff's near-mute ${ }^{3}$ monster, not Stoker's cloak-less Count or Shelley's titular character and his articulate creation. ${ }^{4}$

\section{Theorising Horror}

Carroll advances an understanding of horror based on cognitive psychology. His first step is to distinguish between "art horror" and 
"reality horror". Art horror refers to horror as experienced through the art work, whether this be a canonical classic of Gothic literature or an Italian schlock horror movie like Bruno Mattei's Hell of the Living Dead (1980). Reality horror refers to horror as experienced in the real world, in images of and encounters with war, famine, plague, genocide and so forth. Real horrors can be present within and inspire works of art horror, ${ }^{5}$ just as art horror will often engage with at some level with its real-world counterpart. ${ }^{6}$

Carroll proposes the defining characteristic of art horror is its ability to produce a fundamentally irrational emotional or even physical response 7 , or what he terms "fearing fictions". We know Count Dracula is a character in a novel or played by an actor in a film, yet he nevertheless has the power to frighten, horrify and often disgust us. As far as the last of these powers is concerned, a distinction is made between Carroll's theory and the influential ${ }^{8}$ work of Julia Kristeva (1984). For Kristeva disgust and horror are closely intertwined, with the ultimate figure of horror the inherently "abject" nature of the female body in patriarchy. Carroll agrees abjection is a significant characteristic of horror, but considers it secondary to the monster and disagrees with Kristeva's psychoanalytic approach.

The main reason Carroll's work is preferable as far as Gothic horror is concerned is grounding. Whereas Kristeva's abject applies universally, Carroll's fearing fictions implicate the rational scientific world view associated with modernity. One can only have an irrational fear of vampires, werewolves, bogeymen or flesheating zombies if one knows they do not exist. ${ }^{9}$ This was something intuitively recognised by Bava:

When I hear a noise late at night in my house, I just can't sleep... not to mention dark passages! Sure, I don't believe in vampires, 
witches and all these things, but when night falls and streets are empty and silent, well sure I don't believe, etc., but... I am frightened all the same. Better to stay home and watch TV! (Cited in Howarth, 308)

\section{Italy in Gothic literature and the Italian Gothic cinema}

The relationship between Italy as represented in English Gothic literature of the late eighteenth and nineteenth century and Italian Gothic cinema centres around an apparent paradox. Italy occupied a disproportionately important place in the former, while the latter had a slow and difficult development and was comparatively weak and short-lived. Amongst English Gothic literature we may here consider the likes of Horace Walpole's The Castle of Otranto (1764/65) and Ann Radcliffe's A Sicilian Romance (1790), The Mysteries of Udolpho (1794) and The Italian (1797). In cinema we may note how only a single Gothic horror film was produced in Italy before 1956, namely Eugenio Testa's Il mostro di Frankenstein $(1921)^{10}$ along with the greater success and longevity of the giallo.

The crucial thing in English Gothic literature is how Italy and other foreign countries were used symbolically as points of contrast with Britain, to provide implicit conceptual Others against which the individual and national selves could be defined. A number of oppositions can be identified, including the religious, in terms of Roman Catholicism against Protestantism; temporal, in terms of the past against the present and/or the future; visual, in terms of the clear against the obscured and the illuminated against the shadowy; and those between irrational or superstitious beliefs and rational or scientific knowledge. The foreign would usually be assigned the value deemed negative in each case, though sometimes a more ironic 
treatment was evident. The comparatively limited presence of the Gothic in mid-late nineteenth century Italy and its apparent absence in the Fascist era might correspondingly be seen as a reflection of how Italians increasingly understood themselves to be modern. If irrational fears were to be found, they were better located elsewhere in place and/or time. In this regard it is significant that the inaugural film of the Italian Gothic cycle, I Vampiri ${ }^{11}$ (1956), should have been set in France.

\section{Vampiri}

The body of another young woman, the third in as many months, is fished out of the River Seine. The autopsy reveals she has been exsanguinated, just like the previous cases. The authorities are reluctant to consider the possibility that a vampire could be at large in Paris, 1956. Journalist Pierre Lantin is less sure and hopes to make "the scoop of the century". Pierre's investigations initially seem hampered by the attentions of Giselle Du Grand, the niece of the aged Duchess Du Grand, who had herself sought, without success, to romance Pierre's father three decades earlier. Pierre then discovers the two women are one and the same. The Duchess is the vampire, who uses the women's blood to regain her youthful appearance and pose as her niece. ${ }^{12}$

The first enigma I Vampiri poses is a non-diegetic one: Why the use of the plural, The Vampires, when the film only features a single figure who would normally be considered such? One answer is pragmatic: The gendered nature of the Italian language means Freda would have indicated too early there was a single female vampire had he entitled the film La Vampira. Another is more significant: Freda was primarily interested in a naturalistic treatment of the vampire and in its value as a metaphor. While far removed from the neo- 
realist film-makers of a few years earlier, as demonstrated by his proclamation "I am not in the least interested in banal humanity, everyday humanity", Freda nevertheless understood the vampire in more socio-political terms. As he explained:

I believe in a subtle, psychological kind of horror. No vampires or monsters please-they are vulgar, ridiculous devices. My theory is that authentic terror can be attained with simple, common means. The most terrifying monster is the neighbour who cuts his wife's throat (Cited in Bruschini, 20)

As such, The Vampires of the title might be understood as alluding not just to the Duchess but also entire classes of aristocrats and elderly people who are parasitic upon the lower orders and/or young.

The main impact of Freda's approach content-wise is to present a more scientific, less supernatural approach to the Gothic figure of the vampire. The Duchess is an ordinary woman who is trying to regain her youthfulness through the blood of her young adult victims. She is more comparable to the historical Countess Erzsébet Báthory (1560-1614) than Sheridan Le Fanu's fictional Carmilla (1872) or the 'brides' of Bram Stoker's Dracula (1897). The Duchess possesses no special powers and does not exhibit any of the composite characteristics of the ideal-typical Gothic vampire, whether sensitivity to sunlight and holy water; aversion to crucifixes and garlic; ability to transform into other forms; inability to be seen in mirrors; sleeping in a coffin; drinking her victims' blood, or only capable of being killed in particular ways. Yet, unlike Countess Báthory, the Duchess does not bathe in her victims blood. ${ }^{13}$ Rather, she is the recipient of transfusions. As such, her closest counterpart amongst earlier historical and literary vampires is the title character of Mary Elizabeth Braddon's The Good Lady Ducayne (1896). 
In Braddon's short 'sensation'14 literature story an impoverished young woman, Bertha Rolleston, is appointed as companion to the elderly Lady Ducayne. Bertha soon learns that the Lady's last two companions over the past three years had sickened and died. On their trip to Italy Bertha is afflicted by what the Lady's personal physician, Dr Parravicini, identifies as mosquito bites. Bertha's husband-to-be ${ }^{15}$ Dr Stafford then discovers Parravicini himself had been drawing Bertha's blood with a syringe and injecting it into Lady Ducayne as a means of sustaining her life beyond its natural limits, just as he had done with the Lady's previous companions.

Given this narrative and its dynamics of age and class (if not nationality ${ }^{16}$ ), we might see The Good Lady Ducayne as a palimpsest behind I Vampiri, whether or not Freda was aware of this. Both, after all, are distinctively modern vampire tales, where fears are based around science and the human Other, not the supernatural and the inhuman Other. Even so, there are differences, mostly centring around the distinction between what counted as shocking in the context of nineteenth-century Gothic literature and mid-twentiethcentury Gothic horror film. Freda's narrative is more intensive and accelerated, arguably a further reflection of modernity and the process of space-time compression. I Vampiri's events occur over the course of three months rather than three years. The Duchess's victims are not gradually bled to death, but drained entirely at once. She also shockingly ages before Pierre's and our eyes in a matter of seconds, prefiguring the Count's demise in Fisher's Dracula as he is caught in the sunlight by Van Helsing and disintegrates into dust. ${ }^{17}$ The Gothic doubling of the Countess/Giselle and of Pierre and his father also has no counterpart in Braddon's story. Lady Ducayne always looks aged while the medical figures of Parravicini and Mr Stafford are diametrically opposed in their other characteristics. 
This 'excessive' approach, which would characterise much subsequent Italian horror production, ${ }^{18}$ is further evident in the figure of the Duc Du Grand, the Duchess's devoted/besotted physician husband. For his experiments from a hidden laboratory in the basement of their Paris castle also include the transference of life-essences themselves and bringing a guillotined henchman back from the dead as a kind of Frankenstein's monster/zombie servant. In the film marks around the henchman's neck are visible, but he is proclaimed never to have actually been dead, whereas in the script he was guillotined.

If the Duc can thereby be read as a Frankenstein-type figure, it is also noticeable that he is closer to the archetype of the 'mad scientist'. Unlike Shelley's Frankenstein or The Good Lady Ducayne, with their references to the likes of the Medieval Albertus Magnus, there are no mentions of alchemy or other quasi-magical/proto-scientific discourses in I Vampiri. Instead everything presented within may be explicated in modern, rational, scientific terms. ${ }^{19}$ Another example here is when Lantin tails the man who procures the Duchess's victims to a seemingly abandoned apartment. When he goes back with some gendarmes, the place is occupied (by an ex-gendarme) and looks different. What Pierre fails to realise is that the numbers on the apartments had been changed. ${ }^{20}$

A somewhat more modern and domesticated treatment of the traditional archetypal Gothic location of the castle (Punter and Byron 295) is also evident. The castle is presented not as abandoned or haunted ruins in the midst of nowhere but as the Du Grande's family residence. Whilst it has a dark and secret passage from the main hall to the family crypt within its grounds, in the Gothic manner, the hall itself is well-illuminated rather than conventionally shadowy, being used for a ball attended by the cream of Paris society; now- 
elderly women here provide more of the back-story of the Duchess's attempts to woo Pierre's father thirty years earlier.

The most modern aspect of the film, however, is its protagonist. Excepting the more metaphorical likes of Oedipus, the detective is basically a nineteenth-century creation. Considering his origins in Edgar Allan Poe's Auguste Dupin stories (1841, 1842, 1844), and his subsequent development by Arthur Conan Doyle through the Sherlock Holmes character, it is also clear the character has Gothic associations. For instance, The Hound of the Baskervilles (1902) is at heart a Gothic story about the "explained supernatural" in the by-then well established Radcliffean tradition. Holmes, unwilling to accept "the impossible" in the form of a spectral hound, finally uncovers "the improbable", in the form a dog whose ghostly appearance is due to the villain's using phosphorous to make him glow. ${ }^{21}$

In the context of Italian horror the figure of the (amateur) detective would come to be more closely associated with the giallo than the Gothic. This is apparent in the other two films I wish to examine, though they are again unusual in other regards. The Girl Who Knew Too Much has strong Gothic elements but is not particularly horrific. Conversely Deep Red has strong horrific elements but moves towards the supernatural direction Argento would pursue with Suspiria (1977) and Inferno (1980).

\section{The Girl Who Knew Too Much}

Giallo enthusiast Nora Davis flies from New York to Rome to visit her elderly and frail Aunt Ethel. The night Nora arrives Ethel dies. Going to inform Dr Bassi at the hospital, Nora is knocked out by a mugger. Regaining consciousness she sees a man standing over the body of a young woman, a knife in her back, and promptly faints. 
In the morning Nora is discovered by a policeman. With the body having disappeared, and smelling of alcohol due to the ministrations of a passer-by, Nora finds no-one will believe her story. At her aunt's funeral Nora meets a family friend, Laura Craven Toranni, who invites her to stay at her house, which happens to be near where Nora saw the man. Nora learns that three murders took place in the vicinity years before, with the victims' surnames starting with A, B and C. A colleague of Bassi's suggests she may have "psychically travelled" and witnessed one of these earlier crimes. Fearing that she is being targeted by the killer, Nora turns to her favourite reading matter for guidance. Eventually Nora discovers Laura is the killer and is saved by Laura's husband, the man Nora saw on the steps, before he dies from knife wounds inflicted by his wife.

The place of The Girl Who Knew Too Much in the broader history of the giallo film is a matter of debate. For Bava biographer Tim Lucas $(2007,449)$ it is not particularly important when compared with the subsequent Blood and Black Lace (1964). For genre scholar Gary Needham (2003) The Girl Who Knew too Much served to indicate the giallo film had arrived, due to its literal foregrounding of the theme of jet plane travel, one to be found in a number of later Italian horror/ thriller films more generally ${ }^{22}$ as well as Bava's oeuvre specifically ${ }^{23}$; its highly self-reflexive citations of giallo literature, whether the specifics of "The Alphabet Murders" alluding to Agatha Christie's The A.B.C Murders (1936) or the giallo more generally within the diegesis and the voice-off; and its introduction of a number of key themes, most notably the eye-witness who finds that they will not be believed by the authorities and/or that some vital detail of the crime scene is eluding them. The last of these might also be given a more Gothic inflection, for as Punter and Byron remind us: 
From its beginnings, the literary Gothic has been concerned with uncertainties of character positioning and instabilities of knowledge. Far from knowing everything, like an omniscient narrator, characters-and even narrators-frequently know little or nothing about the world through which they move or about the structures of power which envelop them. (273)

Bava originally sought to make a more comedic film inspired by Hitchcock's thriller-romances. Feeling his leading actors were unsuitable, he then endeavoured to emphasise the more macabre aspects of the story (Howarth 309). This said, The Girl Who Knew Too Much remains a distinctly light-hearted and un-horrific film when compared with most subsequent gialli, whether Bava's own Blood and Black Lace (1964) or the work of Argento and his imitators in the 1970s. It is not a particularly violent film with regard to either form, content or their combination. Most of the violence occurs off-screen. There is also a lack of what Stephen Prince (2003) has termed "stylistic amplification", or the use of medium-specific techniques to heighten the affective impact of images of violence. ${ }^{24}$ While Prince's discussions primarily focus upon Hollywood cinema, he acknowledges European popular and art cinemas as an implicit Other for Hollywood productions of the 1950s and 1960s.

Although not being much of a horror film The Girl Who Knew Too Much is a peculiarly Gothic giallo. In particular, I would argue aspects of what can be read as an unconscious reworking of Jane Austen's Gothic parody Northanger Abbey. Both texts, after all, see a young, naïve and impressionable female protagonist travelling to a strange, unfamiliar place. Both Nora Davis and Catherine Morland also have an understanding of the world shaped largely by their respective preferred reading material, giallo thrillers and the "Northanger horrids" or Gothic novels by the likes of Radcliffe. This can be seen 
from the ways they are introduced in their respective narratives. In the first chapter of Northanger Abbey Austen tells us that:

No one who had ever seen Catherine Morland in her infancy would have supposed her born to be an heroine. Her situation in life, the character of her father and mother, her own person and disposition, were all equally against her. [...]

But from fifteen to seventeen she was in training for a heroine; she read all such works as heroines must read to supply their memories with those quotations which are so serviceable and so soothing in the vicissitudes of their eventful lives.

The opening voice-off in The Girl Who Knew Too Much meanwhile tells us that:

This is the story of a vacation. A vacation in Rome, the dream destination of any American between the age of 16 and 70. Nora Davis was 20 years old. Young, full of life, romantic. She satisfied her desire to escape reality by reading murder mysteries [I libri gialli on the Italian language track]. But this would be the last one. She had sworn as much to her mother. Mrs Ethel, the old family friend with whom she would be staying, was going to make sure she kept her promise.

Both Nora and Catherine then find themselves plunged into (or immerse themselves in) situations akin to those of characters within the fiction they read. These then develop in contrasting directions. Catherine's assumptions are increasingly challenged, until she realises that Bath and Northanger Abbey itself are not the kind of dangerous and exciting Gothic locations found in her fiction, but rather just another part of England: 
Charming as were all Mrs. Radcliffe's works, and charming even as were the works of all her imitators, it was not in them perhaps that human nature, at least in the Midland counties of England, was to be looked for. Of the Alps and Pyrenees, with their pine forests and their vices, they might give a faithful delineation; and Italy, Switzerland, and the south of France might be as fruitful in horrors as they were there represented. Catherine dared not doubt beyond her own country, and even of that, if hard pressed, would have yielded the northern and western extremities. But in the central part of England there was surely some security for the existence even of a wife not beloved, in the laws of the land, and the manners of the age. Murder was not tolerated, servants were not slaves, and neither poison nor sleeping potions to be procured, like rhubarb, from every druggist.

Reflecting Nora's more cross-cultural, international journey and Bava's strong sense of irony, Nora's assumptions are increasingly confirmed. This comes despite Bassi's attempts to reassure her that the real Italy is nothing like what she imagines it to be as they visit the tourist location of the crimes, the Spanish Steps:

Just look around you. Does this look like the kind of place where women get stabbed? Come, this is the real Rome. Where the sun shines bright and the air is clear. A dream, perhaps, a nightmare never.

In her final confrontation with the now clearly insane Laura, Nora might also be considered as encountering a variant on the "madwoman in the attic" of Charlotte Brontës "female Gothic" Jane Eyre (1847); a similar figure reappears in Deep Red. Regardless of their increasingly divergent trajectories, both The Girl Who Knew Too Much and Northanger Abbey nevertheless conclude with their 
female protagonists being paired off. Catherine is to marry Henry Tilney, Nora Dr Bassi.

\section{Deep Red}

The marriage scenario provides a point of contrast with Deep Red. While suggesting a growing bond between its male and female protagonists, Argento's film does not conclude with their union. Another contrast, more important for our purposes, is between the films' approaches to the supernatural. The Girl Who Knew Too Much ultimately rejects the (im)possibility that Nora might have somehow witnessed a scene in the past. It is revealed Nora saw the demise of Laura's fourth victim, a would-be blackmailer, in the actual present. Deep Red presents various images that cannot be rationally explained and, indeed, which challenge the adequacy of scientific discourses. As such, what we have is arguably the definitive giallo film departing from the dominant sub-generic formula in which the supernatural is either absent or explicated. The main boundary between Italian Gothic and giallo horrors thus disappears. Here we have a giallo with a contemporary Italian setting in which not everything 'makes sense'.

At a parapsychology conference in Rome, psychic Helga Ullman detects the presence of a murderer in her audience and predicts they will kill again; that night Helga is murdered. Marc Daly, an English pianist resident in the city, is eye-witness to the crime but finds some vital detail eludes him. After his identity is made public by journalist Gianna Brezzi, Marc is threatened by the killer and thereby compelled to investigate the case. Marc's investigations lead him to 'The House of the Screaming Child' and the discovery that the killer, whose face he saw reflected into a painting, is the mother of his friend Carlo. 
Helga and her associates at the parapsychology conference seek to establish their discourse as a scientific one, indicating that extra sensory perceptions are found in various animal species and in infant humans before they acquire the power of speech. Helga is presented as an anomaly whose psychic powers have persisted into adulthood, but which have nothing whatsoever to do with magic, occultism or foretelling the future. This is, of course, immediately challenged by Helga's making a prediction that comes true; later Gianna, who had attended the conference, describes Helga as a "sort of magician". The sense of something inexplicable and supernatural is also indicated by the way in which Helga and Professor Bardi are observed as they leave the theatre. Whereas the point-of-view shots in Freda and Bava's films were clearly linked with a character's position and perspective, these shots do not. In order to see Helga the observer, presumably Carlo's mother, would also have to be seen by her. There is an invisible presence, one Helga senses. This sense of something spectral and haunting is also apparent, in a more dramatic and stylistically amplified manner, when Helga first feels that there is a killer in the theatre, with the camera dramatically and assaultively swooping in on her.

Theidea of precognition recurs throughout the film, whose images are frequently founded upon patterns of doubling and intensification (Smuts, 2002). Generally when something is introduced it is in a basically innocuous context, such as Marc joking to Gianna that his 'real' reason for playing the piano is that subconsciously he hates his father and is symbolically bashing his teeth in; being blasted by steam from an espresso machine as he makes a telephone call, or passing a road maintenance truck. Later images repeat in more sinister, violent and amplified forms. Bardi has his mouth bashed against a mantelpiece by Carlo's mother; Amanda Righetti, the author of the 
book on modern legends, is drowned in a bath of scalding hot water, and Carlo is dragged to his death by a passing truck.

Sometimes, however, an image is repeated without being particularly intensified. This is apparent when Marc's investigations lead him to Righetti's Ghosts of Today and Legends of the Modern Age, which includes the story of 'The House of the Screaming Child', and thence to the place itself. Righetti's book implies the house is haunted, in a classical Gothic manner, yet Marc does not encounter any ghosts or monsters when visiting it. On his second visit, stemming from belatedly realising a window shown in the book's photograph of the house is no longer there, he does however discover a mummified corpse in a hidden, bricked-up room, perhaps recalling Poe's The Black Cat (1843) and The Cask of Amontadillo (1846). ${ }^{25}$ Marc is then knocked unconscious by the killer, who sets the place alight, but is saved by Gianna's timely arrival.

The most important doubled image within the film, however, is that of Carlo's mother. The first time we and Marc see her is for an instant, as a figure in the bottom left corner of the screen, her face reflected into a painting of faces reminiscent of Edvard Munch's Expressionist painting The Scream (1893). This is easy to miss on a first viewing of the film, but becomes obvious thereafter. The second time is when Marc returns to the apartment at the film's denouement, after he has realised that Carlo, who has frequently been presented as his own double throughout the narrative, could not have been the killer; following Carlo's mother's decapitation when her necklace becomes caught in the mechanism of the apartment lift the final image is of Marc's face reflected in a pool of her blood. 


\section{Summary/Conclusion}

Italian horror films of the 1950s through to the 1980 s can generally be divided up in terms of the Gothic and giallo paradigms. Some important films by three of the major figures within this cinema are difficult to precisely position within one or other of these sub-genres. The first Italian Gothic film since the silent era, Riccardo Freda's I Vampiri, was unusual on account of its contemporary setting and general emphasis upon a modern, scientific treatment of the vampire myth, recalling Good Lady Ducayne more than Carmilla or Dracula. It also foregrounded the importance of the detective, a figure thereafter to be more closely associated with the giallo. The first giallo film, Mario Bava's The Girl Who Knew Too Much, cannot really be considered as a horror film, even by the standards of the day. It does, however, have a strong Gothic element, with its protagonist and narrative being in many respects comparable to Austen's Northanger Abbey. The film sometimes considered the high point of the giallo, Dario Argento's Deep Red, certainly qualifies as a horror film, but also has a strong supernatural element at odds with the sub-genre as a whole along with foregrounding Gothic motifs like the double and the haunted house. A key reason behind the inability to clearly differentiate between Gothic and giallo horror is that both forms can ultimately be traced back to the same sources in modernity and the corresponding emergence of "fearing fictions" as a possibility.

\section{Notes}

1. On the relationship between the noir literature and cinema see Borde and Chaumeton (2002). On the relationship between the film noir and giallo film see Wood (2007). 
2. And now into the twenty first century; as I write this a new version of Dracula directed by Argento and exploiting the current vogue for 3D films is imminent.

3. The monster does not speak in Frankenstein but does, albeit briefly, in the 1935 sequel The Bride of Frankenstein.

4. This remains the case despite the more recent Bram Stoker's Dracula (1993) and Mary Shelley's Frankenstein (1994). Coppola's film purported to tell the original story but nevertheless foregrounded Dracula as the historical Vlad the Impaler and emphasised romance, presenting Mina Harker as the reincarnation of Dracula/Vlad's beloved. Branagh's film was more faithful to its source than previous Frankenstein adaptations, but was not a box-office success.

5. As with Pablo Picasso's Guernica (1937) for instance.

6. For example Skal (1993).

7. As Carroll notes the etymological origins of horrify relate to bristling or hair raising in a literal sense.

8. For example Barbara Creed's The Monstrous Feminine (1993).

9. Being disgusted by the abject is correspondingly more rational in a world where we know about disease vectors.

10. Translating as Frankenstein's Monster the title is of note for emphasising the creation over his creator.

11. The film was released in the US as The Devil's Commandment and as Lust of the Vampire. It was begun by Freda and completed by Bava, Freda having made a bet with his producer that he could make a film in twelve days, then leaving the production when it appeared he would lose.

12. Oddly we never find out what happened to Giselle.

13. Bathory would later be seen bathing in blood in Peter Sasdy's Countess Dracula (1970).

14. Some such works are Gothic, whilst others are not.

15. We may here note the importance of the marriage scenario, as will also be seen in The Girl Who Knew Too Much. 
16. Again there is the trope of an English author presenting a foreigner, in this case an Italian, negatively as Other.

17. The two films take different approaches here, however. Whereas Fisher's film cuts away to special effects sequences, Bava does everything in a single take through the use of make-up that was only visible under certain colours of light. This technique had earlier been used in Rouben Mamoulian's 1930 adaptation of Dr Jekyll and Mr Hyde.

18. See, for example, Totaro's analysis of the role of the set-piece in Italian horror (2003) or McDonagh's (2010) reading of Argento's 1970s and 1980s films.

19. As is typical with such films little no explanation of the life-transference process is provided. Yet we are clearly meant to take it as given, with no-one questioning it diegetically. This contrasts, for instance, with a scene in Lucio Fulci's The Beyond (1981), where one doctor hooks up a cadaver to an ECG machine and is mocked by another for the pointlessness of this action.

20. This scenario has some affinities with Le Fanu's The Room at the Dragon Volant (1872).

21. Holmes dictum actually appears in The Sign of Four (1890). However, in the context of Italian horror cinema it is (mis)quoted in Argento's The Girl Who Knew Too Much-influenced Tenebre (1982) as having come from The Hound of the Baskervilles, which the protagonist reads whilst flying from New York to Rome.

22. For example Argento's The Bird with the Crystal Plumage, Suspiria and Tenebre, Sergio Martino's The Strange Vice of Signora Wardh (1970) and Sergio Pastore's The Crimes of the Black Cat (1973).

23. Also appearing in Baron Blood (1972), Lisa and the Devil (1973) and House of Exorcism (1975); in Bava's final film, Schock (1977) the male protagonist is a jumbo jet pilot.

24. For example the use of hand-held camera and cross-cutting to alternately put the spectator in the position of the straight-razor wielding killer and their victim in murder scenes within Freda's The Ghost and Argento's The Bird with the Crystal Plumage. 
25. Argento has often acknowledged his enthusiasm for Poe, culminating in his contribution to the film Two Evil Eyes (1990) co-directed with George A. Romero. His writing partner on Deep Red, Bernardino Zapponi, was also a Poe enthusiast and had earlier worked with Federico Fellini on the Poe anthology film Spirits of the Dead (1968). Elsewhere in Italian horror cinema Poe's influence can be seen in the likes of Martino's Your Vice is a Locked Room and Only I Have the Key (1971) and Fulci's The Black Cat (1981).

\section{References}

Austen, Jane. Northanger Abbey. 1817. http://www.gutenberg.org/files/121/121h/121-h.htm.

Borde, Raymond and Chaumeton, Étienne. A Panorama of American Film Noir, 1941-1953. San Francisco: City Lights, 2002. Print.

Botting, Fred. Gothic. London: Routledge, 1996. Print.

Braddon, Mary Elizabeth. Good Lady Ducayne. 1896. http://www.horrormasters.com/Text/a0557.pdf

Bruschini. Antonio. Horror all'italiana. Florence: Glittering Images, 1996. Print.

Carroll, Noël. The Philosophy of Horror. London: Routledge, 1990. Print.

Creed, Barbara. The Monstrous-feminine. London: Routledge, 1993. Print.

Günsberg, Maggie. Italian Cinema: Gender and Genre. Basingstoke: Palgrave MacMillan, 2005. Print.

Howarth, Troy. The Haunted World of Mario Bava. Godalming: FAB Press, 2002. Print.

Kristeva, Julia. Powers of Horror. New York: Columbia UP. 1984. Print.

Lucas, Tim. Mario Bava: All the Colours of the Dark. Cincinatti: Video Watchdog, 2007. Print.

McDonagh, Maitland. Broken Mirrors/Broken Minds. Minneapolis: University of MinnesotaPress, 2010. Print.

Needham, Gary. Playing with Genre: An Introduction to the Italian Giallo. 2002. http://www.kinoeye.org/02/11/needham11.php 
194 Keith H. Brown, Gothic/Giallo/Genre: Hybrid Images in...

Prince, Stephen. Classical Film Violence. London: Rutgers, 2003. Print.

Punter, David and Byron, Glynis. The Gothic. Oxford: Blackwell. 2004. Print.

Smuts, Aaron. The Principles of Association: Dario Argentos Deep Red. 2002. http://www.kinoeye.org/02/11/smuts11.php

Totaro, Donato. 'The Italian Zombie Film: From derivation to invention' in Steven Jay Schneider (ed.) Fear Without Frontiers. Godalming, FAB Press, 2003. 161-174. Print.

Wood, Mary. 'Italian Film Noir' in Andrew Spicer (ed.) European Film Noir. Manchester: Manchester UP, 2007. 236-272. Print.

[Received in 15/11/2011. Approved in 19/02/2012] 